\title{
How Much Extent can We Rely on Partial Sampling of Radical Prostatectomy Specimens?
}

\author{
Radikal Prostatektomi Materyallerinde Parsiyel Örnekleme Yöntemi \\ Ne Kadar Güvenilir?
}

\author{
Tuba Dilay Kökenek Ünal, Ayşe Selcen Oğuz Erdoğan*, Nesrin Gürçay**, Murat Alper* * \\ Kayseri Training and Research Hospital, Clinic of Pathology, Kayseri, Turkey \\ *Ankara Children's Hematology and Oncology Hospital, Clinic of Pathology, Ankara, Turkey \\ **Dışkapı Yıldırım Beyazıt Training and Research Hospital, Clinic of Pathology, Ankara, Turkey
}

Abstract

\begin{abstract}
Aim: Prostatic adenocarcinoma is the most common cancer among men in the world and prostatectomy specimens are one of the most commonly encountered materials in pathology laboratories. Histopathological evaluation of radical prostatectomy specimens provides very important prognostic parameters to predict patient's prognosis and to choose an appropriate treatment. There is no globally accepted standard grossing method for radical prostatectomy materials. Different grossing protocols are preferred in different centers considering financial condition, storage spaces, number of technicians and pathological workload.
\end{abstract}

Methods: In this study, we evaluated 50 radical prostatectomy specimens using total and partial sampling methods and compared the results.

Results: As a result of the partial sampling method the number of blocks per case was reduced prominently, and depending on this workload and financial burden also reduced. The correlation between total and partial sampling methods was statistically significant.

Conclusion: Partial sampling method can be a choice of grossing of radical prostatectomy specimens with the help of macroscopic, clinical and radiological findings.

Keywords: Prostate, radical prostatectomy, sampling methods

\begin{abstract}
Amaç: Prostatik adenokarsinomlar dünyada erkeklerde görülen kanserler arasında en yaygın olarak görülen kanser olup radikal prostatektomi materyalleri patoloji laboratuvarlarında en çok takibe alınan materyallerin başında gelmektedir. Prostatektomi materyallerinin histopatolojik incelemesi sonucunda elde edilen prognostik parametreler hastalığın seyri ve uygulanacak tedavi yöntemi konusunda klinisyene yol göstermektedir. Radikal prostatektomi materyalleri için dünya çapında kabul görmüş tek bir örnekleme yöntemi bulunmamaktadır. Farklı merkezlerde farklı yöntemler tercih edilmektedir. Bu tercihte mali sorunlar, arşivleme kapasitesi, personel sayısı gibi faktörler rol oynamaktadır.
\end{abstract}

Metod: Bu çalışmada kliniğimize kabul edilen 50 radikal prostatektomi materyali total ve parsiyel örnekleme yöntemi ile değerlendirilerek sonuçlar karşıllaştııılmıştır.

Bulgular: Parsiyel örnekleme yöntemi sonucunda elde edilen blok sayısında belirgin ve dolayısıyla iş yükünde ve mali yükte bir azalma görülürken sonuçların istatistiksel olarak korelasyon gösterdiği sonucuna varıldı.

Sonuç: Çalışmamı göstermiştir ki, parsiyel örnekleme yöntemi ile klinik için önemli olan parametrelere ulaşlabilmektedir ve klinik ve radyolojik bulgulardan da destek alınarak radikal örnekleme yerine tercih edilebilecek bir yöntemdir.

Anahtar Sözcükler: Prostat, radikal prostatektomi, örnekleme yöntemler
Address for Correspondence/Yazışma Adresi: Tuba Dilay Kökenek Ünal Kayseri Training and Research Hospital, Clinic of Pathology, Kayseri, Turkey E-mail: tubadilay@gmail.com

Received/Geliş Tarihi: 21 March 2016 Accepted/Kabul Tarihi: 23 May 2016
${ }^{\circ}$ Copyright 2017 by The Medical Bulletin of Haseki Training and Research Hospital The Medical Bulletin of Haseki published by Galenos Yayınevi.

- Telif Hakkı 2017 Haseki Eğitim ve Araștıma Hastanesi Haseki Tıp Bülteni, Galenos Yayınevi tarafından basıımıştır.

This study was presented in part as poster presentation at 24th European Congress of Pathology, which was held on 8-12 September 2012, in Prague and published in part in Virchows Archiv. 2012;(Suppl 1): S291. 


\section{Introduction}

Prostatic adenocarcinoma is the most common cancer and second leading cause of cancer death among men in the world (1). The incidence of prostate cancer in early stage had been sharply increased at the end of twentieth century as a result of efficiency of modern cancer scanning programs detecting asymptomatic diseases and developing awareness of the disease (1). Radical prostatectomy is an initial and the most important step in the treatment of prostatic adenocarcinoma because only accurate pathological examination of specimens provides important diagnostic, prognostic, and therapeutic clues. Therefore, there is a considerable increase in the number of radical prostatectomy specimens in pathology laboratories of university and research hospitals. Several different sampling methods are recommended by surgical pathology text books, grossing manuals, and published working group reports. Histopathological evaluation of prostatectomy materials provides important pathologic information such as Gleason score, margin status, and pathologic stage which are crucial for selecting adjuvant therapy and for determining the prognosis (2). Preferred sampling method should provide all these necessary parameters. The 2009 International Society of Urological Pathology (ISUP) Consensus Conference put emphasis on cost restraints and time consuming procedures of total embedding and left to the pathologist's decision and recommended some strict protocols to be followed if partial embedding will be used (3). A survey conducted by the American Society of Clinical Pathologists concluded that only $12 \%$ of pathologists used entire sampling method (4). Another survey performed in our country, Turkey, revealed that $57 \%$ of our pathologists embeded entire gland (5). Total embedding is a costly and time-consuming procedure and causes increased workload in all sampling, blocking, staining, scanning and archiving stages. The aim of this study was to compare the results of total and alternative sampling methods in radical prostatectomy specimens and to investigate the reliability of alternative sectioning methods in terms of key pathologic prognostic parameters.

\section{Methods}

With the approval of institutional review board of Dışkapı Yıldırım Beyazıt Training and Research Hospital (approval ID: 230515.21/17), 50 patients, who underwent radical prostatectomy with the diagnosis of acinar prostatic adenocarcinoma between 2009 and 2011, were randomly included in this study. Originally all samples were assessed according to total embedding protocol as summarized below. Formalin-fixed surgical specimens were weighed, measured and inked carefully. The apical and basal margins were sectioned parallel to the urethra in $5 \mathrm{~mm}$ thickness and serially resected perpendicular to the inked margin. Seminal vesicles and ducts were totally embedded. After that, serial transverse sections of 3-5 mm thickness were made. The sections were evaluated carefully for macroscopically identifiable tumor and dissected into four quadrants as right posterior, left posterior, right anterior and left anterior segments. Each segment was blocked separately and named precisely. Average block number was 38 per case.

All tumor samples were evaluated for key pathologic parameters, such as Gleason score, presence of perineural invasion, extraprostatic extension and pathologic stage.

Then, all cases were reevaluated with selected slides in accordance with partial sampling method by two other pathologists. The limited sampling method was built to include haematoxylin and eosin stained slides representing the whole slice which were selected by skipping every other slice beginning from apical portion as forming an alternate slicing. Slides representing apical margins, bladder neck margins and seminal vesicles were retained. Selection of blocks according to alternate slice method resulted in an average of 22 blocks per case.

\section{Results}

The sampled surgical specimens weighed $45.54 \mathrm{~g}$ on average (range: $21-75 \mathrm{~g}$ ). The specimens were sectioned into 7-12 slices (mean: 7.32). The macroscopic features of the surgical specimens are summarized in Table 1. 37\% reduction was achieved in the number of blocks (Table 2). The sensitivity of partial sampling method for Gleason score 7 was $87.5 \%$, but the sensitivity of partial sampling method for Gleason score $\geq 7$ was $8 \% 4$. However, the specificity of alternative method for Gleason score $\leq 7$ was $44 \%$ (Table 3). For extraprostatic extension, the sensitivity and specificity rates were $61.5 \%$ and $100 \%$, respectively. The correlation rates between two sampling methods were $70.3 \%$, and $60 \%$, respectively for extraprostatic extension and pathologic stages. There was complete correlation in surgical margin and perineural invasion evaluation between the two sampling methods. Alternative slicing and total sampling methods provided identical pathologic stage in $76 \%$ of cases (Table 4 ). All correlation rates were statistically significant $(p<0.001)$.

\section{Statistical Analysis}

Statistical analysis was performed by using SPSS for Windows Version 15.0 Software Package and Cohen's Kappa statistics was used to measure the agreement of two sampling methods.

\section{Discussion}

Radical prostatectomy specimens are one of the most common materials which pathologists encounter in routine 
practice. For grossing radical prostatectomy specimens, many protocols and recommendations have been proposed, but general consensus has not been achieved yet (3,6-11). Although recent conference of the ISUP concluded that partial methods were also acceptable (3), there are still controversies on partial sampling of radical prostatectomy materials. In macroscopic examination, recognizing tumoral areas is often difficult, especially in early stages (12-14). Therefore, some pathologists prefer total embedding as the safest method $(5,13)$. On the other hand, many studies revealed that limited sample methods also provided key histopathologic parameters (14-17). In terms of partial sampling of radical prostatectomy materials, there are many different approaches $(14,18)$. In the presence of grossly visible tumor, it is recommended to embed proximal and distal margins, seminal vesicles, visible tumors with relevant margins and susceptible other tumor foci (19). Some guidelines also recommend embedding of the posterior aspects of every transverse slice and single mid anterior slice form each side in addition to proximal and distal margins and seminal vesicles in the absence of grossly visible tumor (19). In this study, we preferred to perform alternate slicing method as one of the partial sampling methods. It is a simple, easy-to-use method and allows the pathologist or inexperienced residents good orientation of unsampled tissue in case of necessity. In the case of macroscopically identifiable tumor, it can be appropriate to include extra blocks representing all tumoral or suspected areas. In some centers, digital images of gross specimens are taken and saved (20). It is also a useful method to reevaluate macroscopic appearance of slices in some circumstances.

\begin{tabular}{|l|l|l|l|l|l|}
\hline Table 1. Macroscopic features of surgical specimens \\
\hline & Mean & Median & Standard deviation & Minimum & Maximum \\
\hline Weight & $45.54 \mathrm{gr}$ & $42.50 \mathrm{gr}$ & $13.964 \mathrm{gr}$ & $21 \mathrm{gr}$ & $75 \mathrm{gr}$ \\
\hline Number of slices & 7.32 & 7.00 & 1.285 & 5 & 12 \\
\hline The largest diameter & $5.06 \mathrm{~cm}$ & $5.00 \mathrm{~cm}$ & $1.018 \mathrm{~cm}$ & $3 \mathrm{~cm}$ & $9 \mathrm{~cm}$ \\
\hline gr: Gram, cm: Centimeter
\end{tabular}

\begin{tabular}{|c|c|c|c|c|c|}
\hline & \multirow[t]{2}{*}{ Mean (n) } & \multirow[t]{2}{*}{ Median (n) } & \multirow[t]{2}{*}{ Standard deviation (n) } & \multicolumn{2}{|c|}{ Number of blocks per specimen } \\
\hline & & & & Minimum & Maximum \\
\hline Total sampling & 37.98 & 35.50 & 7.795 & 27 & 61 \\
\hline Partial sampling & 22.56 & 22.00 & 4.643 & 10 & 33 \\
\hline
\end{tabular}

\begin{tabular}{|l|l|l|l|l|l|}
\hline Table 3. Gleason scores achieved by total and partial sampling method & \multicolumn{3}{|c|}{ Gleason score (total sampling) (p) } \\
\cline { 2 - 6 } & & $\mathbf{2 - 6}$ & $\mathbf{7}$ & $\mathbf{8 - 1 0}$ & Total (n) \\
\hline \multirow{2}{*}{ Gleason score (partial sampling) (p) } & $2-6$ & 10 & 3 & 0 & 12 \\
\cline { 3 - 6 } & 7 & 8 & 21 & 6 & 35 \\
\hline Total (n) & $8-10$ & 0 & 0 & 2 & 2 \\
\hline n: number of cases, p: points & & 18 & 24 & 8 & 50 \\
\hline
\end{tabular}

\begin{tabular}{|c|c|c|c|c|c|c|}
\hline & & \multicolumn{4}{|c|}{ Pathologic stage (total sampling) (n) } & \multirow[b]{2}{*}{ Total $(n)$} \\
\hline & & T2a & T2c & T3a & T3b & \\
\hline \multirow{4}{*}{ Pathologic stage (partial sampling) (n) } & $\mathrm{T} 2 \mathrm{a}$ & 7 & 3 & 1 & 0 & 11 \\
\hline & $\mathrm{T} 2 \mathrm{c}$ & 1 & 24 & 2 & 3 & 30 \\
\hline & T3a & 0 & 0 & 2 & 2 & 4 \\
\hline & $\mathrm{T} 3 \mathrm{~b}$ & 0 & 0 & 0 & 5 & 5 \\
\hline Total $(n)$ & & 8 & 27 & 5 & 10 & 50 \\
\hline
\end{tabular}


In addition, in the presence of preoperative needle biopsy reports, additional samples from positive quadrants can be taken. In comparison with total embedding method, the alternate slicing method successfully estimated all histopathologic predictive parameters and had a statistically significant correlation with total sampling in our study. We obtained identical Gleason score in 34 of the cases (68\%). When we consider interobserver variability and reproducibility levels for Gleason scoring, this partial sampling method provided good correlation (21). We obtained complete correlation in perineural invasion and surgical margin evaluation between the two methods. Partial sampling method was failed to detect extraprostatic extension only in five of the cases (10\%). However, we assume that it is a reasonable result, because there was no complete concordance in interpretation of extraprostatic extension among even expert pathologists (22). In addition to that, partial sampling method is a very practical and time-saving method providing an important reduction in block numbers and reducing financial costs in pathology laboratories.

\section{Conclusion}

In conclusion, although the limited sampling protocol provides statistically significant results, because of the critical role of pathological assessment in the treatment of prostatic adenocarcinoma, it can be found unsatisfactory by some pathologists. However, we think that with the help of advanced radiologic modalities, and macroscopic and clinical findings, an alternate slicing method can be preferred and it can provide key prognostic parameters.

\section{Ethics}

Ethics Committee Approval: This study was approved by Ethics Committee of Board of Dışkapı Yıldırım Beyazit Training and Research Hospital with approval ID: 230515.21/17. Informed Consent: It was taken.

Peer-review: Internally peer-reviewed.

\section{Authorship Contributions}

Surgical and Medical Practices: Tuba Dilay Kökenek Ünal, Ayşe Selcen Oğuz Erdoğan, Nesrin Gürçay. Concept: Tuba Dilay Kökenek Ünal, Ayşe Selcen Oğuz Erdoğan, Murat Alper. Design: Tuba Dilay Kökenek Ünal, Ayşe Selcen Oğuz Erdoğan, Murat Alper. Data Collection or Processing: Tuba Dilay Kökenek Ünal. Analysis or Interpretation: Tuba Dilay Kökenek Ünal, Ayşe Selcen Oğuz Erdoğan. Literature Search: Tuba Dilay Kökenek Ünal, Nesrin Gürçay. Writing: Tuba Dilay Kökenek Ünal.

Conflict of Interest: No conflict of interest was declared by the authors.

Financial Disclosure: The authors declared that this study received no financial support.

\section{References}

1. Siegel RL, Miller KD, Jemal A. Cancer statistics, 2015. CA Cancer J Clin 2015;65:5-29.

2. Kench JG, Clouston DR, Delprado W, et al. Prognostic factors in prostate cancer. Key elements in structured histopathology reporting of radical prostatectomy specimens. Pathology 2011;43:410-9.

3. Samaratunga $H$, Montironi $R$, True $L$, et al. International society of urological pathology (ISUP) consensus conference on handling and staging of radical prostatectomy specimens. working group 1: specimen handling. Mod Pathol 2011;24:615.

4. True LD. Surgical pathology examination of the prostate gland. Practice survey by American society of clinical pathologists. Am J Clin Pathol 1994;102:572-9.

5. Doganavsargil B, Nalbantoglu I, Hekimgil M. Handling and reporting of radical prostatectomy specimens: A practice survey among pathologists. Turkish Journal of Pathology 2007;23:74-81.

6. Egevad L. Handling of radical prostatectomy specimens. Histopathology 2012;60:118-24.

7. Gill PS, Roberts IS, Browning $L$, et al. The handling and sampling of radical prostatectomy specimens for reporting and research: the Oxford approach. J Clin Pathol 2012;65:105761.

8. Ohori M, Kattan M, Scardino PT, Wheeler TM. Radical prostatectomy for carcinoma of the prostate. Mod Pathol 2004; 17:349-59.

9. Sung MT, Davidson DD, Montironi R, Beltran AL, Cheng L. Radical prostatectomy specimen processing: A critical appraisal of sampling methods. Diagn Histopatol 2007;13:490-8.

10. Sringley JR. Key issues in handling and reporting radical prostatectomy specimens. Arch Pathol Lab Med 2006;130:303-17.

11. Montironi R, Van der Kwast T, Boccon-Gibod L, Bono AV, Boccon-Gibod L. Handling and pathology reporting of radical prostatectomy specimens. Eur Urol 2003;44:626-36.

12. Renshaw AA. Correlation of gross morphologic features with histologic features in radical prostatectomy specimens. Am J Clin Pathol 1998;110:38-42.

13. Bell KB, Kida M, Cooper K. Histopathology sampling of radical prostatectomy specimens: representative or entire submission? Histopathology 2011;59:1013-4.

14. Sehdev AE, Pan CC, Epstein Jl. Comparative analysis of sampling methods for grossing radical prostatectomy specimens performed for nonpalpable (stage T1c) prostatic adenocarcinoma. Hum Pathol 2001;32:494-9.

15. Kim K, Pak PJ, Ro JY, Shin D, Huh SJ, Cho YM. Limited sampling of radical prostatectomy specimens with excellent preservation of prognostic parameters of prostate cancer. Arch Pathol Lab Med 2009;133:1278-84.

16. Llanos CA, Blieden C, Vernon SE. Processing radical prostatectomies: an alternate-slice method is comparable with total embedding. Ann Diagn Pathol 2012;16:284-7. 
17. Vainer B, Toft BG, Olsen KE, Jacobsen GK, Marcussen N Handling of radical prostatectomy specimens: total or partial embedding? Histopathology 2011;58:211-6.

18. Doganavsargil B, Hekimgil M, Simsir A, Cal C, Soydan S. A study on histological prognostic factors and partial sampling methods in radical prostatectomy. Ege J Med 2002;41:133-41.

19. Association of Clinical Pathologists. Guidelines for the macroscopic processing of radical prostatectomy and pelvic lymphadenectomy specimens. J Clin Path 2008;61:713-21.
20. Trpkov K, Warman L. Use of digital maps and sampling of radical prostatectomy specimens. Arc Pathol Lab Med 2006;130:1751-2.

21. Kuroiwa K, Shiraishi T, Ogawa O, et al. Discrepancy between local and central pathological review of radical prostatectomy specimens. J Urol 2010;183:952-7.

22. Evans AJ, Henry PC, Van der Kwast TH, et al. Interobserver variability between expert urologic pathologists for extraprostatic extension and surgical margin status in radical prostatectomy specimens. Am J Surg Path 2008;32:1503-12. 